\title{
ABTB2 Gene
}

National Cancer Institute

\section{Source}

National Cancer Institute. ABTB2 Gene. NCI Thesaurus. Code C90175.

This gene may play a role in hepatocyte growth. 